\title{
Burdur Gölü ve Çevresinin Peyzaj Değerleri Açısından Turizm Potansiyelinin Belirlenmesi
}

\author{
Ayşegül KAPLAN ${ }^{1 *}$, Ömer Kamil ÖRÜCÜ2 \\ ORCID 1: 0000-0001-6917-7232 \\ ORCID 2: 0000-0002-2162-7553 \\ ${ }^{1}$ Süleyman Demirel Üniversitesi, Fen Bilimleri Enstitüsü, Peyzaj Mimarlığı Ana Bilim Dalı, 32260, Isparta, Türkiye. \\ ${ }^{2}$ Süleyman Demirel Üniversitesi, Mimarlık Fakültesi, Peyzaj Mimarlı̆ı Bölümü, 32260, Isparta, Türkiye. \\ *e-mail: aysegulkaplan9@gmail.com \\ Öz \\ Ulusal ve yerel ölçekte ekonomiye ve insan yaşantısına katkısı olan turizm ve rekreasyon faaliyetlerinin doğru ve \\ etkin gelişimi için doğal ve kültürel değerlerin korunması, planlı ve sürdürülebilir gelişiminin dikkate alınması \\ gerekir. Turizm ve rekreasyon faaliyetleri deniz, kum, güneş üçüsü ile sınırlı kalmayıp kırsal kesimlere de \\ yayılmış durumdadır. Çalışmada Burdur ili'ndeki turizm ve rekreasyonel alanların ne ölçüde kullanıldığı ile doğal \\ ve kültürel özellikleri tespit edilerek sorunlarının ve niteliklerinin ortaya konması amaçlanmıştır. Turizm ve \\ rekreasyonel potansiyeli olan alanların tespiti ve yerel halk ile günübirlik ziyaretçilerin kullanım eğilimleri anket \\ tekniği ile belirlenmiştir. Uygulanan anketten elde edilen veriler ArcMap 10.0 ile değerlendirilerek haritalar \\ oluşturulmuştur. Turizm ve rekreasyon potansiyel özellikleri olan alanların tespiti ve sorunlarının da \\ belirlenmesini hedefleyen bu çalışmada medeni hal ve cinsiyetin kullanım tercihleri ile alan kullanım tarzları \\ arasında anlamlı ilişkiler olduğu görülmüştür. Sonuçta, kullanım biçimleri ile demografik veriler arasındaki \\ ilişkiye dayanarak 1/1.000.000 ölçekli, Burdur ili turizm ve rekreasyon potansiyeli haritası oluşturulmuştur. Elde \\ edilen bu haritada Burdur ili'nin turizm ve rekreasyon kapsamındaki gelişimi ve bu bağlamda alınması gereken \\ önlemler ilgili öneriler geliştirilmiştir.
}

Anahtar Kelimeler: Burdur, turizm, rekreasyon, potansiyel.

\section{Determination of Tourism Potential in Terms of Landscape Values of Burdur Lake and Its Surroundings}

\begin{abstract}
In order to achieve an efficient and correct development of tourism and recreational activities, which contribute to economy and public life at national and local scales, preservation and sustainable planned progress of cultural and natural values should be taken into account. In recent years, tourism and recreational activities have spread to rural areas other than beaches and seashores. This study aims to consider to what extent touristic and recreational grounds of Burdur are used and to present the issues and quality of these grounds by determining their natural and cultural values. By conducting a survey applied to local people and same-day visitors, potential grounds for tourism and recreational activities and their usage tendency are determined. Using the results of this survey, we prepared maps via ArcMap 10.0. In this work, it is observed that there are
\end{abstract}

Atıf: Kaplan, A., Örücü, Ö.K. (2019). Burdur Gölü ve Çevresinin Peyzaj Değerleri Açısından Turizm Potansiyelinin Belirlenmesi. Mimarlık Bilimleri ve Uygulamaları Dergisi (MBUD), 4 (2), 105-121. DOI: $\underline{10.30785 / \mathrm{mbud} .555622}$ 
correlations between marital status and gender, and how these touristic and recreational grounds are used. Conclusively, a 1/1.000.000-scale map of potential tourism and recreational activity grounds of Burdur illustrating the relationship between the usage style and demographic info is prepared. In this map, suggestions regarding the development of Burdur Province within the scope of tourism and recreation. Measures to be taken in this context have also been developed.

Keywords: Burdur, tourism, recreation, potential.

\section{Giriş}

Insanlar, boş zamanlarını değerlendirmek ve yenilenip tazelenerek günlük yaşantılarında daha yüksek motivasyon sahibi olmak amacı ile rekreasyonel faaliyetlerde bulunurlar. Rekreasyonel faaliyetlere katıım gün geçtikçe daha büyük önem arz etmektedir. Bu faaliyetlere katılım sağlandığı kadar, kısa süreli tatillere yönelik talep de gün geçtikçe artmaktadır. Bu durum bireylerin hem dinlence amaçı seyahat etmek, hem de bu tatillerde rekreasyonel faaliyetlerini gerçekleştirmek eğiliminde olduklarını ortaya koyar (Can, 2015).

Günümüzde yoğun ve stresli iş temposu, şehir kalabalığı, trafik gibi nedenlerle insanlar iş dışında kalan zamanlarını dinlenmek, arınmak ve tazelenmek için kullanmak istemektedirler. Bu istek, dış mekân koşullarında ya da kapalı alanlarda giderilebilir. Günübirlik kullanım şekli olarak rekreasyon ya da konaklama içeriğine sahip olmasıyla rekreasyondan ayrılan turizmin de ortak paydası olan arınmışlık ve tazelenmiş duygusu, bu zamanların etkin dinlenme ve nitelikli geçirilmesi ile mümkündür.

Teknolojinin gelişmesi ve buna paralel olarak ulaşılabilirliğin artması ile turizm ve rekreasyonel faaliyetlerin gerçekleşme biçimlerinde önemli değişiklikler gözlenmektedir. Gelişip değişen bu turistik ve rekreasyonel faaliyetler, aktivitenin gerçekleştiği coğrafya ile doğrudan bir etkileşim içindedir. Bu yüzden doğal ve kültürel peyzaj değerleri, turizm potansiyelini belirleyen başlıca değerler olarak görülebilir.

Peyzaj, doğa ve bu kavramlarla ilişkili ve karşılıklı etkileşim içinde olmak günümüz şartlarında oldukça önemlidir. Bu önem doğru peyzaj planlaması ve yönetimi, bununla ilintili olarak hedef peyzaj alanlarının doğru tanınması ve sürdürülebilirliğinin devam ettirilebilmesi esasına dayanır. Doğa ile bağlantılı rekreasyon, turizm ve rekreasyon çerçevesinde bir alanın ticari bir alan olarak kullanımına imkan tanımakta ve hizmet sunmaktadır. Bu nedenle, doğal alanlardaki hassasiyetler ve mevcut kullanımlar dikkate alınmalı, doğru bir yön haritası çizilmeli, yatırımlar bu doğrultuda yapılmalıdır.

Turizm konusundaki çalışmalarda ve gerçekleştirilen planlamalarda genel olarak katıımcı amaçları dikkate alınır (Gıran Taşçığlu, 2016). Türkiye'de kıyı turizmi etkinlikleri ile başlayan turizm faaliyetleri zaman içinde değişip gelişerek çeşitlenmiştir. Özellikle son yıllarda turizm politikalarını, Avrupa Birliği ve Dünya Turizm Örgütü’nün öngörüleri şekillendirmektedir. Sürdürülebilir turizm ve kalkınma ilkeleri doğrultusunda alternatif turizm politikaları geliştirilerek kırsal turizm, yayla turizmi, ekoturizm, köy turizmi, kuş gözlemciliği gibi turizm faaliyetleri öne çıkarılmaktadır (Zeğerek, 2016).

Bir bölgeye ait kültürel varlıklar ön plana çıkarılarak turizm desteklenir, diğer turizm ve rekreasyon faaliyetleri de bu değerlere göre düzenlenirse o bölge kısa sürede bir cazibe merkezi haline gelecektir. Bu aşamada kültür turizmi kavramı önem kazanmaktadır. Kültür turizmi; bireylerin kültürel intiyaçlarının karşılanması amacıyla devamlı yaşadıkları yerden seyahat ederek yeni bilgi ve deneyimler elde ederek bu kültürel intiyaçlarının giderilmesi olarak ifade edilebileceği gibi, bir kültüre ait ürünlerin değerlendirilerek kullanılması şeklinde de tanımlanabilir (Richards, 1996). Mehrhoff (1991) ise kültür turizmini geniş bir anlam bütünü içinde değerlendirmiş ve ziyaretçilerin gittikleri yerdeki tarihi, kültürel ve ulusa ait kıymetler bütününü deneyimlemesi, öğrenmesi ve olarak tanımlamıştır. Bu, bölgedeki kültürel değerleri ve mirası, sanat eserlerini, etnik ve kültürel etkinliklerini birer ürün olarak ziyaretçilerin kullanımına hizmet olarak sunmak anlamı taşımaktır. Bu tarz bir gelişim o bölgenin ekonomik ve sosyal yönden gelişimini desteklerken, bölgedeki istihdamın ve çeşitli kaynaklara yapılacak yatırımın artmasına kalıcı bir zemin hazırlayacaktır. Ayrıca bölgenin kalkınması için yenilenebilir bir kaynak olarak hizmet verecektir. 
Doğanın turistik ve rekreasyonel kullanıma bu denli zemin olma ve kaynak oluşturmasına karşın tüm bu faaliyetlerin olumsuz yöndeki etkileri incelendiğinde; kaynakların korunması için doğanın korunması bakımından önemli tedbirler alma zorunluluğu dikkat çeker. Bu noktada turizmin kendisi değil, gerçekleşme biçimi itibari ile ekonomik çıkarını, doğa koruma ilkesinden daha ön planda tutmasından kaynaklanmaktadır. Bu nedenle bulunduğu coğrafya üzerinde kalıcı tahribata yol açabilecek olan faaliyetler ile ilgili bir takım düzenlemeler ortaya konmalı ve yaptırımlarla uygulanmalıdır. Buna ek ve kurtarıcı bir önlem olarak da bölgenin sosyal, kültürel özellikleri ve mevcut peyzaj değerleri doğru tespit edilmelidir. Bununla birlikte bölgede yaşayan halkın bölgeyi kullanım eğilimleri de doğru saptanmalıdır.

Çalışmanın temel amacı; Burdur ili'nin turizm ve rekreasyonel kullanım amacı ile öne çıkan alanlarını belirleyerek o bölgede yaşayan yerel halkın dinlence-eğlence eğilimlerini tespit etmek, yerel kullanıcı profilini ortaya koymak ve yanıtlar ile anlam ilişkisi bulunan unsurları belirlemektir. Bu amaçla Burdur ili'ndeki turizm ve rekreasyonel kullanım alanlarını kapsayan çalışmada, anketlerden elde edilen yanıtlar ile ilin rekreasyonel amaçlı kullanım tarzını belirlemek ve turizm, rekreasyon potansiyeli yüksek alanları tespit etmek hedeflenmiştir. Ortaya konan veriler, Göller Yöresi'nde bulunan Burdur Ili'nin doğru ve etkin kaynak kullanımını desteklerken, temel bazı eksiklikleri de saptamayı amaçlamaktadır.

Burdur ili'nde değerlendirilmesi gerekli bir turizm ve rekreasyon potansiyelinin varlı̆ı̆ı öngören bu çalışma, bölgeye ait turizm ve rekreasyon değerlerini ortaya koymuş ve bu değerlerin korunması, geliştirilmesi üzerine fikirler geliştirirken; elde edilen bulgular ışığında Burdur illi'nde üzerinde çalışılmaya ve geliştirilmeye ihtiyaç duyulan alanların tespit edilmesine katkı sağlamıştır. Belirlenen temel eksikliklerin giderilmesi ve mevcut durumun iyileştirilmesi için de öneriler sunmaktadır.

\section{Materyal ve Yöntem}

\subsection{Materyal}

Çalışmanın ana materyalini, Burdur ili'nin turizm ve rekreasyon alanları oluşturmaktadır. Yardımcı materyalini ise turizm ve rekreasyon potansiyeli kavramları ile ilgili kitap, makale ve bilimsel araştırma sonuçları, Burdur ilii ile ilgili raporlar, ilgili kurum ve kuruluşlarla yapılan sözlü görüşmeler, basılı ve elektronik ortamdaki dergi ve yayınlar oluşturmaktadır. Çalışmanın amacı doğrultusunda gerekli analiz ve değerlendirme çalışmalarının yapılabilmesi için ilgili kurum ve kuruluşlardan elde edilen her türlü harita, broşür, belge, basılı ve elektronik ortamdaki bilgiler de materyal olarak kullanılmıştır.

Burdur ili, Göller Yöresi ismi verilen bölgede, Akdeniz Bölgesi'nin iç kesiminde bulunmaktadır. Akdeniz Bölgesi'nden Ege ve Orta Anadolu Bölgeleri'ne geçiş alanında, 29-24' ve 30-53' Doğu Boylamları ve $36^{\circ}-53^{\prime}$ ve $37^{\circ}-50^{\prime}$ Kuzey Enlemleri arasında yer alır. Burdur, güneyde Antalya, batıda Denizli, güneybatıda Muğla, doğu ve kuzeyde Isparta ve Afyon illeri ile çevrilidir. İlin yüzölçümü 7.176 $\mathrm{km}^{2}$, rakımı 950 metredir (URL-1). Burdur Ili'nin merkez ilçeden sonra gelen en büyük ilçe merkezi Bucak olup Ağlasun, Altınyayla, Bucak, Çavdır, Çeltikçi, Gölhisar, Karamanlı, Kemer, Tefenni, Yeşilova (Şekil 1) olmak üzere 11 ilçesi vardır. 


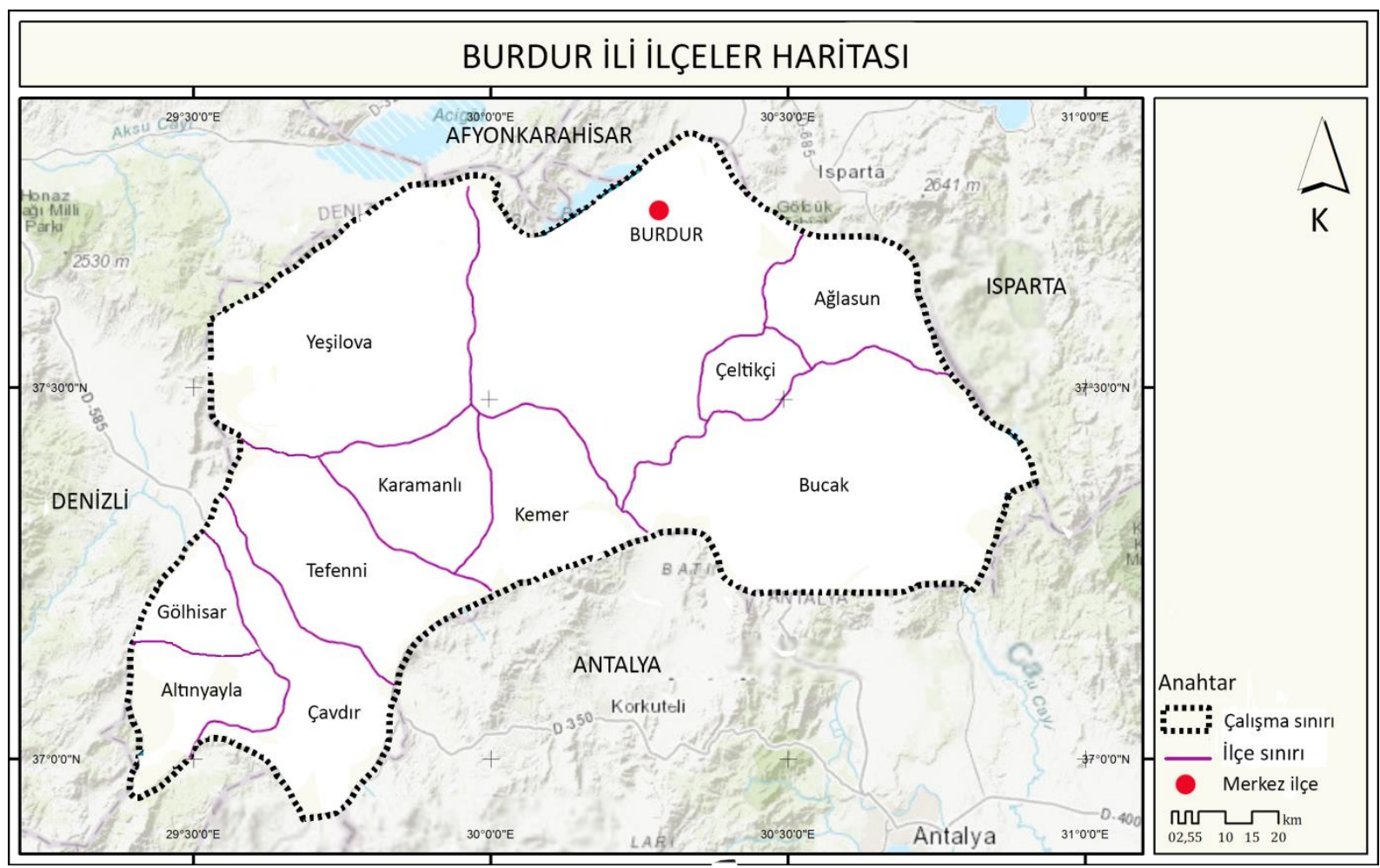

Şekil 1. Burdur ilii ilçeleri haritası (Orijinal, 2019)

\subsubsection{Doğal bitki örtüsü}

Burdur ili, yükseklik; iklim ve toprak yapısı bakımından çeşitlilikler barındırmaktadır. Bu durum vejetasyon yapısı üzerinde doğrudan etkiye sahiptir.

Bucak ilçesinin kuzeydoğusundaki Asar Tepe kuzey yamaçlarının 1.200 metreden yüksek seviyeleri Lübnan Sediri ve Toros Göknarı'nın hâkim olduğu yarı nemli ormanların doğal yayılış alanıdır. Ihlamur (Tilia rubra subsp. caucasica), kızılcık, fındık, titrek kavak, üvez (Sorbus torminalis), kasnak meşesi (Quercus vulcanica) gibi türlerin karıştığı bu ormanlar; batı kesimde Söğüt Dağları, Salda Gölü'nün kuzeyindeki ve güneyindeki dağlık alanlar ile Burdur Gölü depresyonu güneyindeki 2.334 metre yüksekliğindeki Kestel Dağı üzerinde yerlerini kızılçam, karaçam, ardıç türlerinden oluşan kuru ormanlara bırakırlar. Burdur'da Bucak çevrelerinde, Isparta'da Sütçülerde, Antalya'da Aksu Çayı'nın kollarından Pınargözü Deresi ve Çürükiri Deresi vadilerinde topluluklar oluşturur. Çoğunlukla Fraxinus angustifolia, Ulmus minor, Salix alba, Pinus brutia, Platanus orientalis, Alnus orientalis subsp.orientalis ve maki türleri ile görülür (Günal, 2013).

Burdur Gölü'nün güneydoğusunda Bayındır ve Bereket Köyü dağlarında ardıç ağaçları bulunmaktadır. Burdur Gölü'nden sonra başlayan orman tamamen karaçamdan oluşmaktadır. Kapaklı ve Çamoluk (Aziziye) Köyleri arasında seyrek kızılçamlar bulunurken, Kestel Dağı'nı zirvelerinde yaşlı meşeler ve ardıçlar vardır. Yeşilova'nın batısında bulunan Eşeler Dağı'nda karaçam, Salda Gölü'nün çevresinde kızılçam ormanları, Burdur Gölü'nün batısındaki Söğüt Dağları'nda ise ardıç ve seyrek karaçam ormanları bulunmaktadır (URL-2). Burdur ilii'ne ait vejetasyon haritası Şekil 2' de gösterilmiştir. 


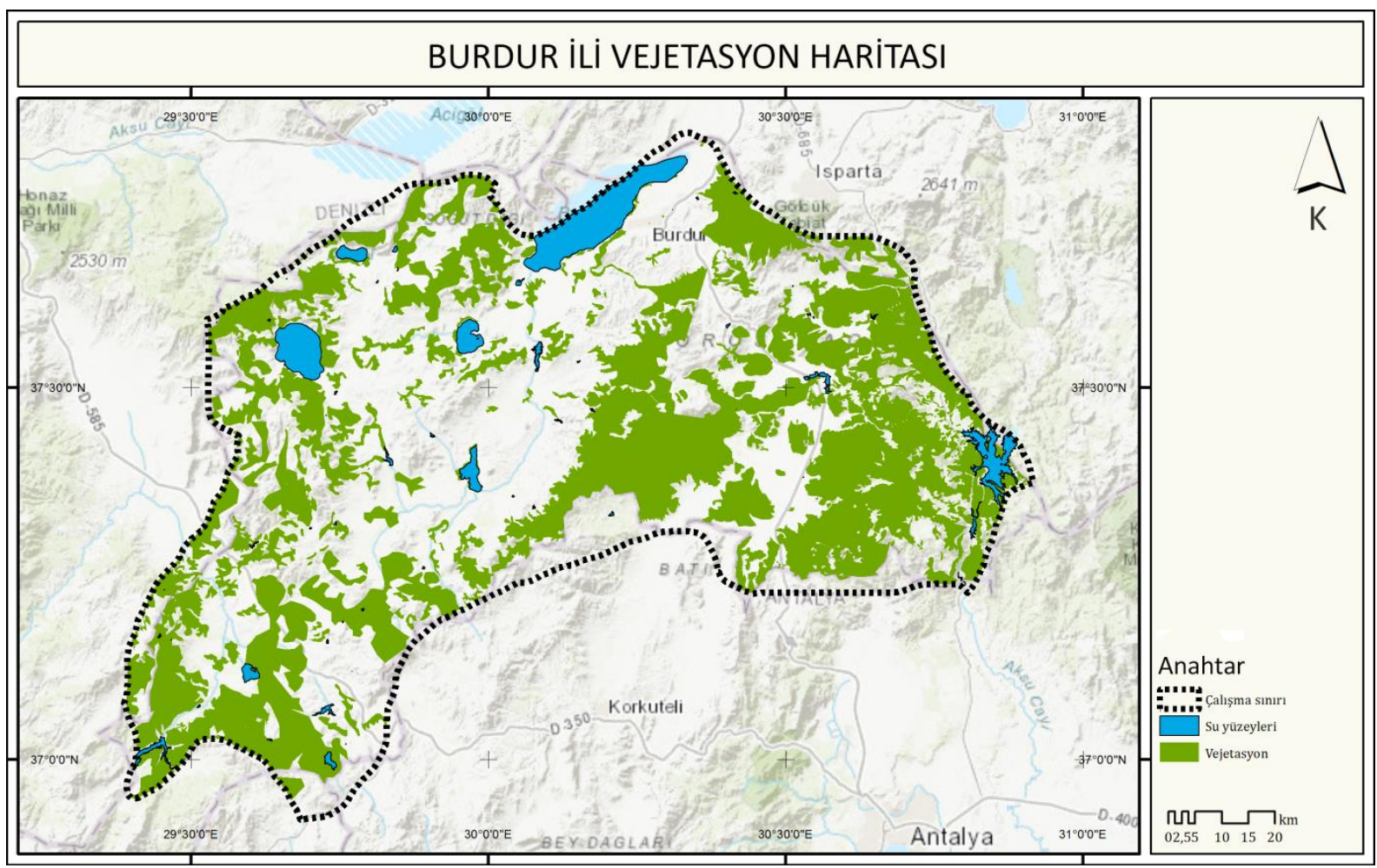

Şekil 2. Burdur îli vejetasyon haritası (Orijinal, 2019)

\subsection{2. iklim}

Göller Yöresi'nde 14 göl ile göller bakımından en zengin il olan Burdur'un iklimi bölgesel olarak değişkenlik göstermektedir. Yeryüzü şekillerinin değişken olması, iklimin de değişken olmasına neden olmaktadır. Bu durum yörenin Akdeniz'e bakan yamaçlarında Akdeniz ikliminin dağ karakterleri etkili olması ve bu suretle Akdeniz ve Orta Anadolu step iklimi geçiş özelliklerini göstermesinden kaynaklanmaktadır (Evliyaoğlu, 1994). Bu nedenle bölge; Akdeniz bölgesine göre daha az yağış almasına rağmen iç̧ Anadolu step iklimine göre daha fazla yağış almaktadır (Öztaş ve Karabulut, 2007).

\subsubsection{Jeomorfolojik yapı}

Torosların iç kesiminde yer alan Burdur, dalgalı plato görünümündedir. Yüzey şekilleri açısından il; topraklarını çevreleyen dağlar ve aralarına sıkışmıs düzlükler, güney ve güneydoğudaki yüksek yaylalar ve güneybatıdaki taban kesimi ovalık engebeli plato olmak üzere üç ana bölüme ayrılabilir. ì arazisinin \% 60,6'sı dağlık, \% 2,7'si yayla, \% 19'u ova \% 17,6'sı engebelidir. II toprakları tektonik ve karstik çöküntü alanlarını kapsar. Bu nedenle sularla dolu çöküntü çanaklarının, vadilerin, mağaraların ve dehlizlerin bulunduğu bölge Göller Bölgesi adını almıştır (URL-3).

Burdur ili jeomorfolojik yapısını tanımlayan eğim (Şekil 3), bakı (Şekil 4) ve yükseklik (Şekil 5) durumu haritalar ile ifade edilmiştir. 


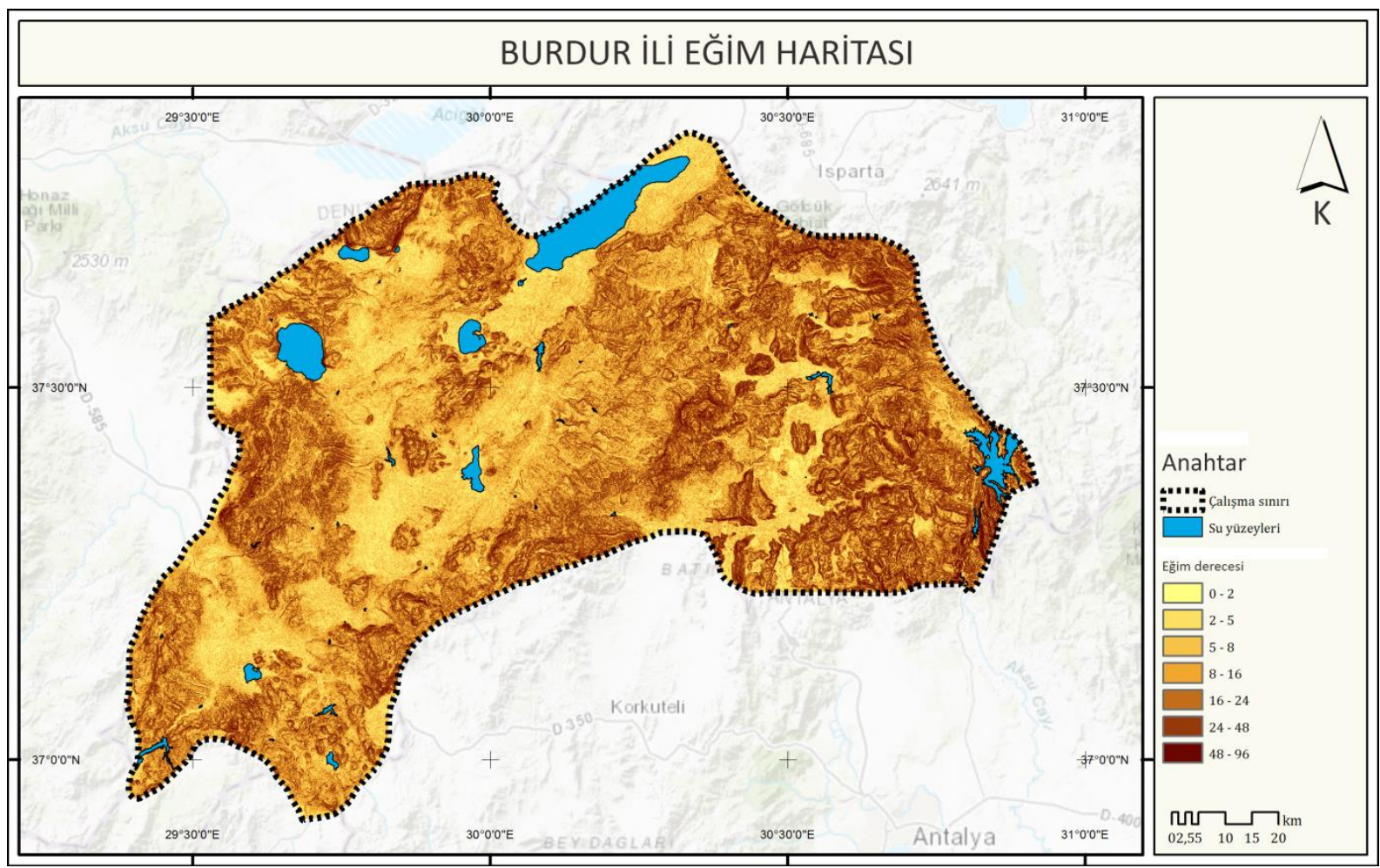

Şekil 3. Burdur ilii eğim haritası (Orijinal, 2019)

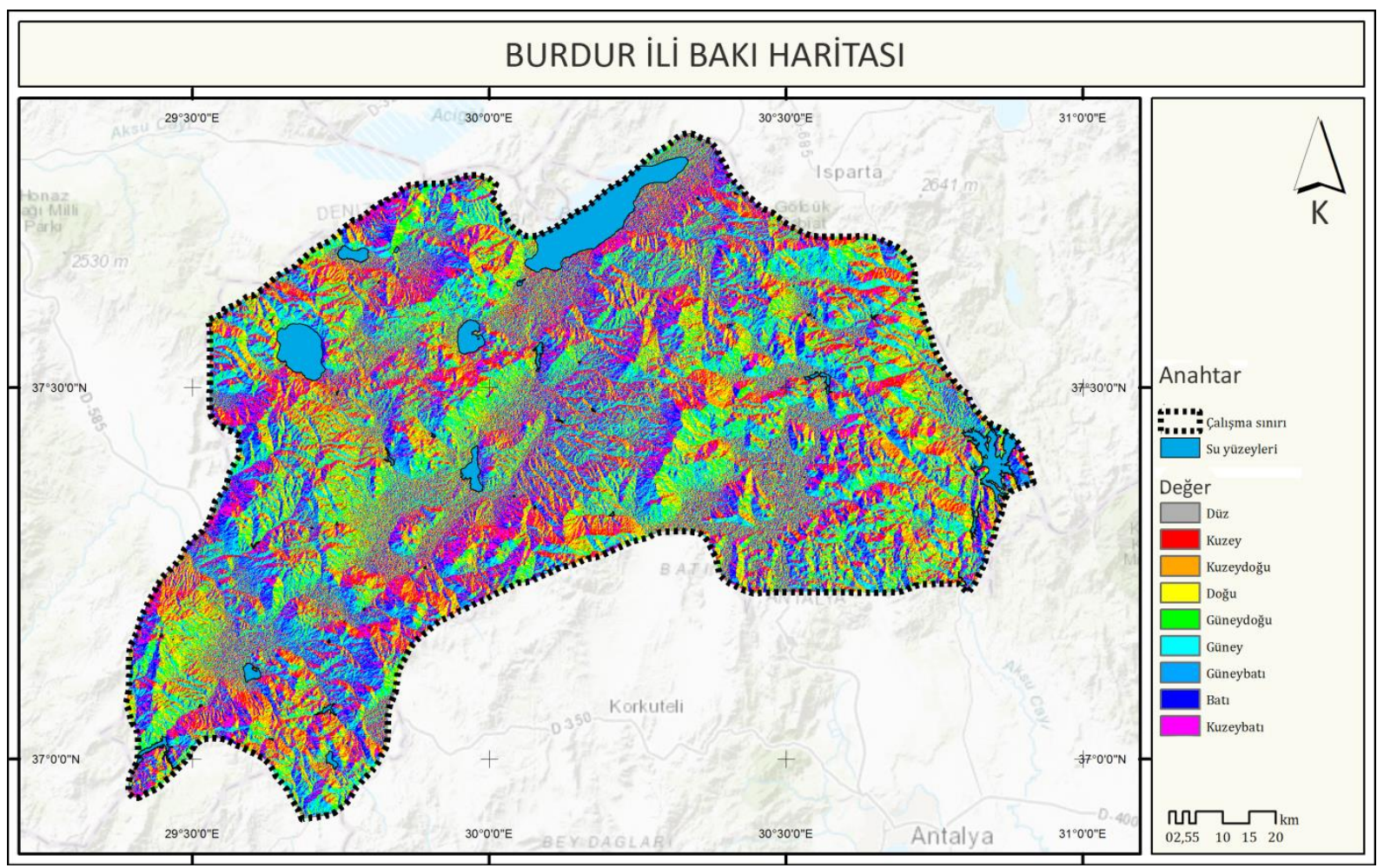

Şekil 4. Burdur İli bakı haritası (Orijinal, 2019) 


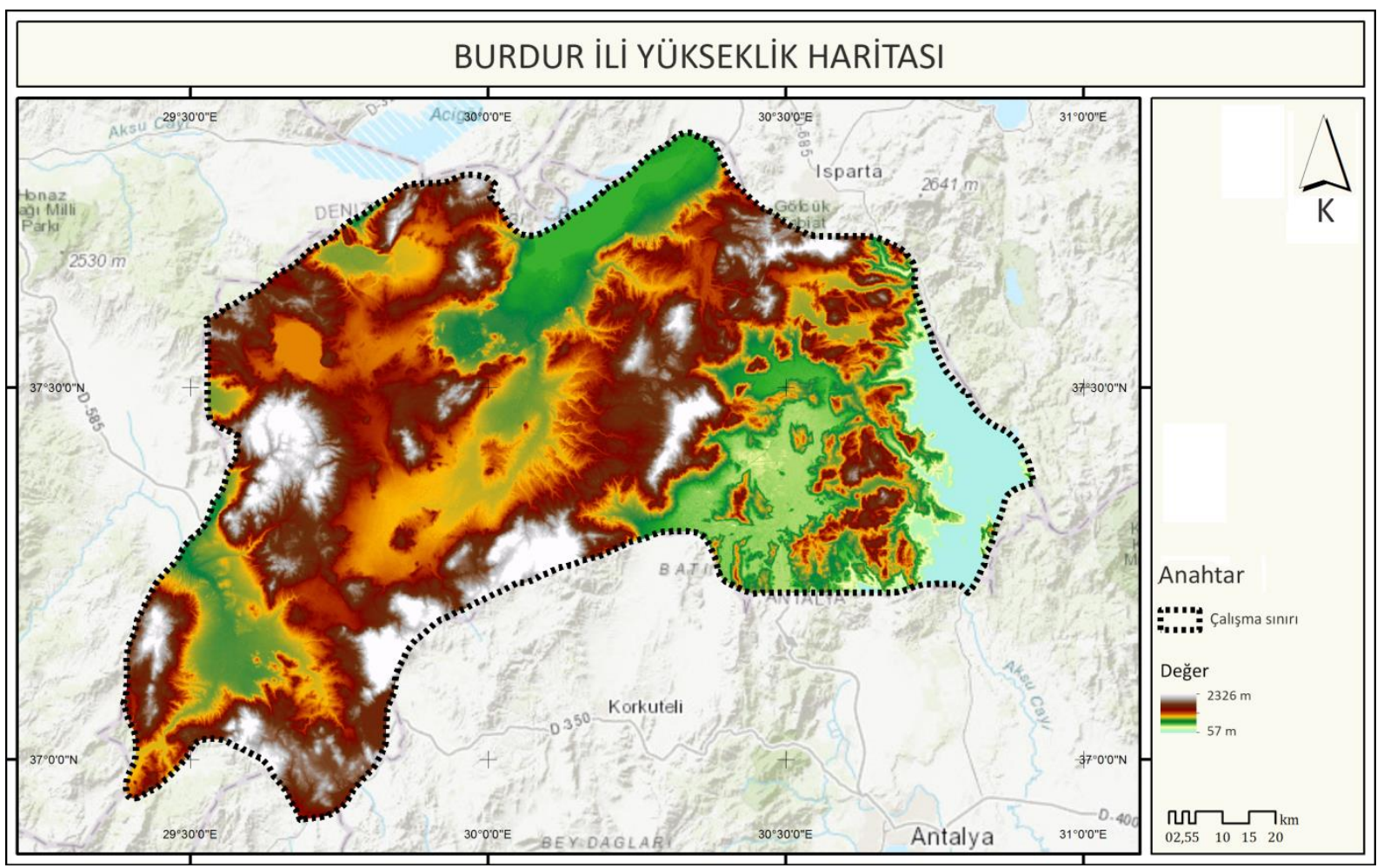

Şekil 5. Burdur illi yükseklik haritası (Orijinal, 2019)

\subsubsection{Hidrojeolojik yapı}

Burdur, Isparta, Afyonkarahisar, Konya ve Denizli il sınırlarına yayılan ve çok sayıda birbirine yakın gölün bulunduğu bölge, coğrafi özelliklerini de yansıtacak şekilde Göller Yöresi ismini almıştır. Göller Yöresi, Akdeniz Bölgesi'nin Anadolu iç kesimine uzanan bir parçasıdır ve Burdur ili tamamen bu yörenin içinde bulunmaktadır. Burdur ili'nde, birbirinden farklı özelliklere sahip olan Burdur Gölü, Salda Gölü, Karataş Gölü, Yarışlı Gölü, Gölhisar Gölleri başta olmak üzere mevsimsel olarak seviyesi azalan ya da suyu tamamen çekilen irili ufaklı pek çok göl bulunmaktadır. Yaban hayatı ve doğal peyzajın korunması açısından önem sahibi olan bu göller, yöre insanının yaşamı üzerinde de oldukça etkilidir. (URL-4).

Burdur İli, Göller Yöresi'nde olmasından dolayı göller ve bu gölleri besleyen akarsular bakımından çeşitli özelliklere sahiptir. Burdur'da büyük nehir ve ırmaklar bulunmaz ancak akarsu bakımından zengindir. Eşeler Dağı'ndan çıkan Alakır Çayı, 45 kilometrelik bir yatağı izleyerek Kıravgaz Dağı'ndan çıkan Kıravgaz Çayı, Leften Yaylası'ndan çıkan Askeriye Çayı 15 kilometrelik bir yatağı izleyerek Burdur Gölü'ne dökülmektedir. Tekkegözü'nden çıkan Arvallı Çayı 20 kilometrelik bir yatağa sahip olup Çeltikçi Çayı ile birleştikten sonra Onaç Çayı adını alır ve Kestel Gölü'ne dökülmektedir. Başköy yöresinden çıkan ve 25 kilometrelik bir yatağı izleyen Başköy Çayı, Aksu Çayı́na dökülmektedir. Burdur îli sınırları içinde 30 kilometrelik bir yatağı olan Dalaman Çayı, Gölhisar yöresinde bulunan en büyük akarsu olma özelliğine sahiptir ve Ege Denizi'ne dökülmektedir (URL-5). Ayrıca, mevsimsel yağıs miktarına bağlı yüzeysel akışa geçen Kanlı Dere, Sultan Dere, Akdere ve Burdur Çayı gibi kuru dereler de bulunmaktadır (Ala, 2001).

Burdur îli sınırlarında kaynağı bulunan ve yatağı Burdur ili'nden geçerek il sınırları içine dökülen çay ve akarsuların bulunduğu harita Şekil 6 'da gösterilmiştir. 


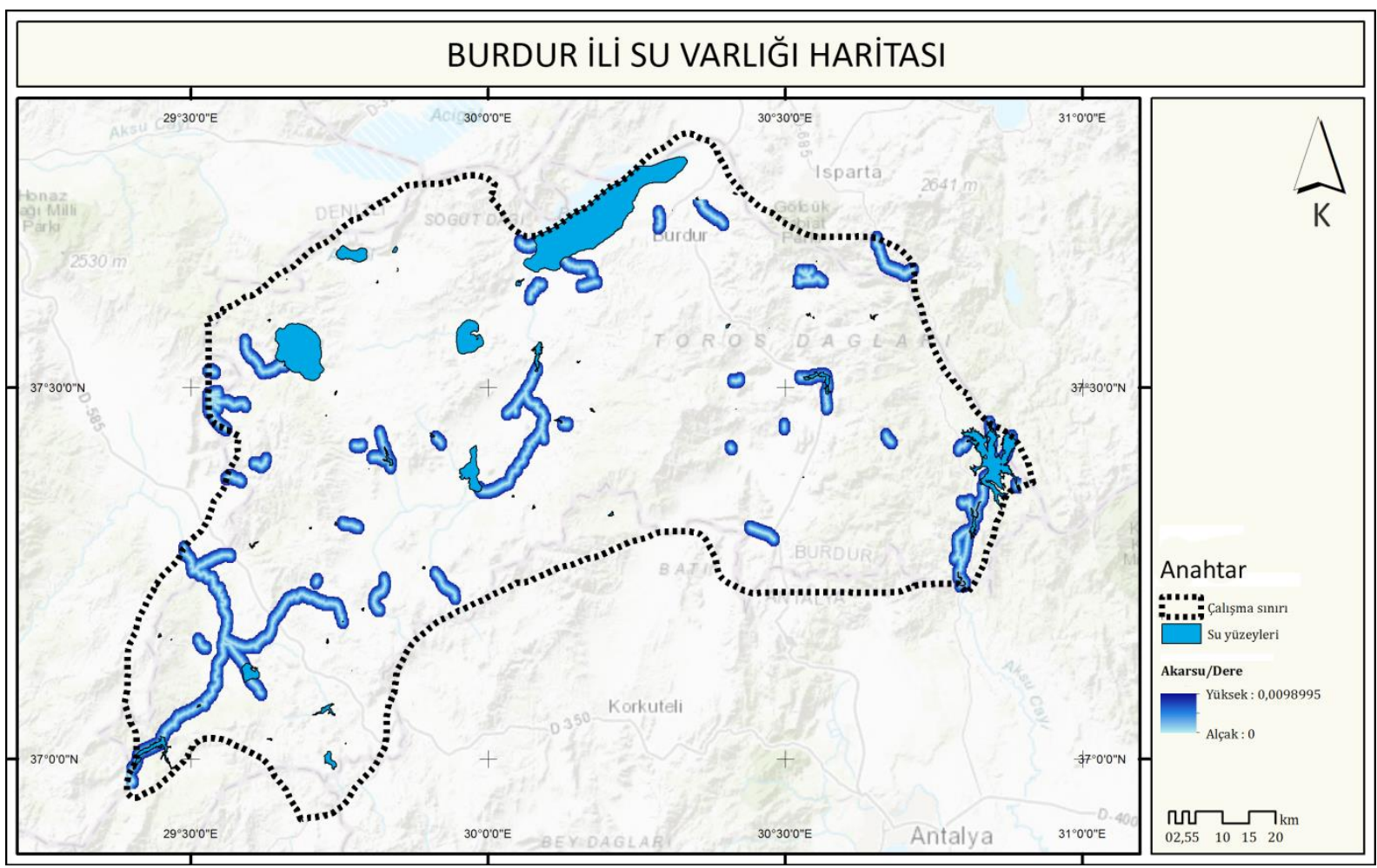

Şekil 6. Burdur İli su varlığı haritası (Orijinal, 2019)

\subsection{Yöntem}

Burdur ili'nde yürütülen araştırma, arazi ve ofis çalışması olmak üzere iki yönlü ve üç aşamalı olarak yürütülmüştür.

Araştırmanın birinci aşaması olan arazi gözlem ve literatür taraması aşamasında; konu ile ilgili daha önce yapılmış çalışmalar, hazırlanan kaynaklar, çalışma alanına ait makaleler, tezler, bildiriler, seminerler, raporlar, bilimsel araştırma projeleri ve kitaplardan bilgi edinilmiştir. Arazi çalışmalarında Burdur ili'ne ait turizm ve rekreasyon merkezleri ziyaret edilmiş ve buralarda vakit geçirilerek gözlem yapılmıştır. Fotoğraf makinesi, video kamera ve drone ile çalışma alanına ait görüntüler elde edilmiştir. Yerinde gözlemlerin dışında, çalışma alanına ait verileri sağlamak için ilgili kurum, kuruluş ve sivil toplum örgütlerinden elde edilen tanıtım araçları, harita ve görsel kaynaklar incelenmiştir. ilgili kurumlardaki meslek mensupları ile sözlü görüşmeler yapılmıştır.

Araştırmanın ikinci aşaması olan ofis çalışması, birinci aşamada elde edilen bilgiler doğrultusunda ilerlemiştir. Burdur ili'ndeki turizm ve rekreasyon amaçlı kullanım alanlarının yerel halk tarafından kullanımını tespit etmeye yönelik bir anket hazırlanmıştır. Burdur ili içindeki rekreasyonel kullanım alanlarındaki kullanıcı tercihlerini saptamak için günübirlik kullanım yapan, yakın çevreden gelen ziyaretçiler ve yerel halk seçilmiştir. Örneklem büyüklüğü, TÜik' in 2017 yılında adrese dayalı nüfus sisteminden alınan bilgiye göre Burdur ili toplam nüfusu olan 264.779 olarak belirlenmiştir. (URL-6), Anket sayısını belirlemek için Yazıcıoğlu ve Erdoğan (2004)'da belirtilen örneklem büyüklüğü tablosu dikkate alınmıştır. Yapılacak olan anket sayısının saptanmasında $\alpha=0,05$ (standart hata) için $\pm 0,05$ örneklem hatası ile evren büyüklüğü 100.000 'in üzerindeki nüfus için öngörülen en az 386 denek sayısı temel alınmıştır.

Internet ortamında yayınlanabilir halde ve basılı olmak üzere aynı içerikte Türkçe olarak hazırlanan anket, 3 bölüm ve 17 sorudan oluşmaktadır. Anket kapsamında Burdur Il'inde rekreasyonel kullanım eğilimleri ve bu eğilimlerin temel özelliklerini belirlemeye yönelik sorular sorulmuştur.

Anketin ilk bölümünde ziyaretçilerin rekreasyonel aktivitelere katılım durumu öğrenilmiştir. 
İkinci bölümde kullanıcının rekreasyonel aktivitelere katılmayı isteyip istemediğini tespit edecek bir soru sorulmuştur. Verilen hayır yanıtı ile anket tamamlanırken, evet yanıtı ile anketin üçüncü bölümüne geçilmektedir. Hayır yanıtı veren anketler değerlendirmeye alınmamıştır.

Üçüncü bölümde katılımcılara Burdur illi sınırları içerisinde yer alan rekreasyonel kullanım alanlarından hangilerini tercih ettikleri ve kullanımları sırasındaki deneyimlerini öğrenmeye yönelik sorular sorulmuştur. Bölüm sonunda ise kullanıcıların demografik ve sosyo-ekonomik durumlarının belirlenmesi amaçlanmıştır.

Araştırmanın üçüncü aşamasında, anketler değerlendirmeye tabi tutulmuştur. Bu değerlendirmede elde edilen anket verilerinin birbiri ile olan ilişkileri; anket uygulaması sonucu toplanan verileri çeşitli istatistik metotlar ile analiz etmek için kullanılan bir bilgisayar yazılımı olan SPSS (Statistical Package for the Social Sciences, Sosyal Bilimler için İstatistik Programı)'de incelenmiştir. Analiz edilen veriler daha sonra ki-kare $\left(\mathrm{x}^{2}\right)$ bağımsızlık analizine tabi tutulmuş ve yanıtlar arasındaki anlamlılık durumları incelenmiştir (Özbay, 2008). Ki-kare $\left(x^{2}\right)$ bağımsızlık analizi; iki değişken arasında bir ilişki bulunup bulunmadığını veya gözlenen ve beklenen frekans dağılımları arasındaki farkların rastgele hatalardan olup olmadığını kontrol etmek için kullanılan bir yöntemdir (Kubat ve Ayaşlıgil, 2002). Analiz sırasında hangi değişkenin bağımsız hangi değişkenin bağımlı olduğunun önemi yoktur. Analiz sonucunda ortaya çıkan ve anlamlılık değerini ifade eden $p$ değeri (phi value); bu iki değişkenin birlikte olma olasılığını ifade etmektedir. Bu değer; $p=0,000$ 'a yaklaştıkça değişkenlerin arasında anlamlı farklııklar yüksek derecededir, $p=0,050$ 'ye yaklaştıkça ise ilişki zayıflamaktadır. Değişkenler analiz edildikten sonra $p$ değerinin $p \geq 0,050$ olduğu durumlarda anlamlı bir farklılık yoktur şeklinde ifade edilmiştir. íki değişken için hazırlanan tablolarda, katımcıların yanıt vermedikleri hücre sayısı çapraz karşılaştırmanın toplamının \%20'sinin üzerinde çıktı̆̆ında, bu iki değişken için ki-kare testi uygulanmamıştır.

Uygulanan anketten elde edilen veriler, temelde 4 soru üzerinden değerlendirilmiş ve Burdur ïli Turizm ve Rekreasyon Potansiyeli Haritası elde etmek için kullanılmıştır. Bu aşamada Örücü (2002)' nün "Eğirdir Yöresindeki Mevcut Peyzaj Değerlerinin Turizm Açısından İrdelenmesi" çalışmasında kullandığı formül esas alınmıştır. Bu formül;

Bir alanın Turizm ve Rekreasyon Potansiyeli $=\mathrm{TRP}_{\mathrm{i}}$;

$T R P_{i}=A_{i}+B_{i}+C_{i}+\left(-D_{i}\right)$ şeklinde ifade edilmiştir. Bu formüldeki parametreler ise; $A_{i}$, alan değeri, $B_{i}$ sosyo kültürel faktörlerin uygunluğu, $C_{i}$ rekreasyonel ve turistik altyapı faktörlerinin uygunluğu, $D_{i}$ olumsuz çevre faktörleri olarak ele alınmıştır.

Formül uygulanan alanlar; turizm ve rekreasyon potansiyel uygunluğu bakımından 5 gruba ayrılmıştır. Çalışma alanı;

- Turizm ve rekreasyon potansiyeli uygun olmayan,

- Turizm ve rekreasyon potansiyeli az uygun,

- Turizm ve rekreasyon potansiyeli orta uygun,

- Turizm ve rekreasyon potansiyeli uygun,

- Turizm ve rekreasyon potansiyeli çok uygun olarak gruplandırılmıştır.

Değerlendirmenin temelinde, Burdur ili'ndeki alan tipi tercihleri, beğenilen sosyo-kültürel özellikleri ile altyapı özellikleri pozitif değerli ve olumsuz çevre koşullarına verilen yanıtların frekans değerleri üzerinden elde edilen katsayılar da negatif değerli olarak kullanılmıştır. Frekans; çoklu seçim yapılabilecek sorularda bir soruya verilen toplam yanıtın tüm yanıtlar içindeki görülme sıklığının yüzde olarak ifade edilmesi anlamı taşımaktadır. Elde edilen bu katsayılar, ArcMap 10.0 programında $1 \mathrm{~km}^{2}$ lik alanlara bölünerek oluşturulmuş Burdur ili haritasına aktarılmıştır. Anket sorularına ait seçeneklerinin kullanıcılar tarafından belirlenen katsayıları, Burdur il haritası üzerinde belirlenmiş noktalara işlenerek bir turizm potansiyeli haritası elde edilmiştir.

\section{Bulgular}

Çalışma alanına yönelik hazırlanmış ankete verilen yanıtlara göre; Burdur ili'ndeki rekreasyonel kullanımlarda, göl ve göl manzarası olan alanlar ilk sırada gelmektedir. Katılımcıların \% 31,36'sı göl ve 
göl manzarası olan alanları rekreasyonel aktiviteler için tercih etmektedirler. Bu da suyun dış mekân rekreasyonu için oldukça önemli bir unsur olarak öne çıktığını gösterir.

Turizm ve rekreasyon potansiyeli haritası oluşturmak için kullanılan anket sorularına ait "Dinlenceeğlence amaçlı etkinliklerde bulunmak için ne tür alanları seçersiniz?" sorusuna ait seçenekler harita üzerinde belirlenerek anketlerden elde edilen uygun katsayı değerleri ile çarpılmıştır. Sorunun yanıtları bölgenin turizm ve rekreasyon potansiyeli değerini artıran yanıtlardır ve pozitif toplam olarak alınmıştır (Çizelge 1).

Çizelge 1. Turizm ve rekreasyon potansiyeli haritası oluşturmak için kullanılan katsayı değerleri -1-

\begin{tabular}{|c|c|c|c|c|}
\hline & $\begin{array}{l}\text { Dinlence - eğlence amaçlı etkinliklerde bulunmak için ne tür alanları } \\
\text { tercih edersiniz? }\end{array}$ & $\begin{array}{l}\text { Yanıt } \\
\text { sayısı }\end{array}$ & Yüzde (\%) & $\begin{array}{r}\text { Katsayı } \\
\text { (a) }\end{array}$ \\
\hline 1 & Göl manzaralı yerler & 259 & 31,36 & 3,14 \\
\hline 2 & Akarsu-dere kıyısı & 138 & 16,71 & 1,67 \\
\hline 3 & Yayla-mesire alanları & 132 & 15,98 & 1,60 \\
\hline 4 & Müzeler-Örenyerleri & 120 & 14,53 & 1,45 \\
\hline 5 & Kent ormanları & 100 & 12,11 & 1,21 \\
\hline 6 & Kayak merkezleri & 64 & 7,75 & 0,78 \\
\hline 7 & Dalış noktaları & 13 & 1,57 & 0,16 \\
\hline
\end{tabular}

"Gezmiş olduğunuz yerlerin en çok hangi sosyo-kültürel özelliğini beğendiniz?" sorusuna ait yanıtlar ele alınırken bölgede festival ve şenliklerin yapıldığı alanlar, tarihi ve anıtsal niteliğe sahip noktalar, bölgenin geleneksel mimarisini en iyi yansıtan örneklerin bulunduğu yerler ile geleneksel el sanatları örneklerinin görülebileceği mekânlar ve ibadet noktaları belirlenmiştir. Belirlenen bu noktalara Çizelge 2'de görülen katsayı değerleri verilmiştir ve pozitif toplam olarak değerlendirilmiştir.

Çizelge 2. Turizm ve rekreasyon potansiyeli haritası oluşturmak için kullanılan katsayı değerleri -2-

\begin{tabular}{|c|c|c|c|c|}
\hline & $\begin{array}{l}\text { Gezmiş olduğunuz yerlerin en çok hangi sosyo-kültürel özelliğini } \\
\text { beğendiniz? }\end{array}$ & $\begin{array}{l}\text { Yanit } \\
\text { sayısı }\end{array}$ & Yüzde (\%) & $\begin{array}{r}\text { Katsayı } \\
\text { (b) }\end{array}$ \\
\hline 1 & Festival ve şenlikler & 211 & 33,18 & 3,32 \\
\hline 2 & Tarihsel anıt ve mekânlar & 152 & 23,9 & 2,39 \\
\hline 3 & Geleneksel mimari & 149 & 23,43 & 2,34 \\
\hline 4 & Geleneksel el sanatları & 97 & 15,25 & 1,53 \\
\hline 5 & Dinsel değerler & 27 & 4,25 & 0,43 \\
\hline
\end{tabular}

"Gezmiş olduğunuz yerlerin en çok hangi altyapı özelliğini beğendiniz?" sorusuna ait yanıtlar ele alınırken bölgedeki ulaşım ağları, güvenli oluşuna dair bir kriter için polis ve jandarma merkezleri, yeme içme olanakları bakımından restoranlar ve kırsal alanlardaki küçük işletmelerin bulunduğu noktalar, park ve bahçelerin varlığı ile konaklama merkezleri dikkate alınmıştır. Tüm bu noktalar, Çizelge 3'te gösterilen katsayı değerleri ile çarpılarak pozitif toplam olarak değerlendirilmiştir.

Çizelge 3. Turizm ve rekreasyon potansiyeli haritası oluşturmak için kullanılan katsayı değerleri -3-

\begin{tabular}{|l|r|r|r|r|}
\cline { 2 - 5 } \multicolumn{1}{l|}{} & $\begin{array}{l}\text { Gezmiş olduğunuz yerlerin en çok hangi altyapı özelliğini } \\
\text { beğendiniz? }\end{array}$ & $\begin{array}{r}\text { Yanıt } \\
\text { sayısı }\end{array}$ & Yüzde (\%) & $\begin{array}{r}\text { Katsayı } \\
\text { (c) }\end{array}$ \\
\hline $\mathbf{1}$ & Ulaşılabilirlik & 227 & 31,44 & 3,14 \\
\hline $\mathbf{2}$ & Güvenilir olması & 206 & 28,53 & 2,85 \\
\hline $\mathbf{3}$ & Yeme-içme olanakları & 108 & 14,96 & 1,50 \\
\hline $\mathbf{4}$ & Çevre düzenlemesi & 97 & 13,43 & 1,34 \\
\hline $\mathbf{5}$ & Konaklama olanakları & 84 & 11,63 & 1,16 \\
\hline
\end{tabular}

Turizm ve rekreasyon potansiyeli ve uygunluğun belirlenmesi için negatif katsayı olarak ele alınan; "Gezdiğiniz alanlardan yararlanmanızı etkileyen olumsuz çevre faktörleri nelerdir?" sorusudur. Seçeneklerin değerlendirilmesinde yerinde gözlemlerden faydalanılmıştır. Engellilere yönelik uygun kullanım \% 0 - \% 5 eğim derecelerinin uygunluk varsayılarak ele alınmıştır (Çizelge 4). 
Çizelge 4. Turizm ve rekreasyon potansiyeli haritası oluşturmak için kullanılan katsayı değerleri -4-

\begin{tabular}{|c|c|c|c|c|}
\hline & $\begin{array}{l}\text { Gezdiğiniz alanlardan yeterince yararlanmanızı engelleyen olumsuz } \\
\text { çevre faktörleri nelerdir? }\end{array}$ & $\begin{array}{l}\text { Yanıt } \\
\text { sayısı }\end{array}$ & Yüzde (\%) & $\begin{array}{r}\text { Katsayı } \\
\text { (d) }\end{array}$ \\
\hline 1 & Görsel kirlilik & 208 & 23,61 & 2,36 \\
\hline 2 & WC-kabin eksikliği & 179 & 20,32 & 2,03 \\
\hline 3 & Su kirliliği & 151 & 17,14 & 1,71 \\
\hline 4 & Engellilire yönelik kullanım olmayışı & 101 & 11,46 & 1,15 \\
\hline 5 & Kalabalık oluşu & 68 & 7,72 & 0,77 \\
\hline 6 & Güvenli olmayışı & 66 & 7,49 & 0,75 \\
\hline 7 & Gürültü & 65 & 7,38 & 0,74 \\
\hline 8 & Hava kirliliği & 43 & 4,88 & 0,49 \\
\hline
\end{tabular}

Çalışmada; Burdur ili'nde turizm ve rekreasyon açısından önemli alanlar, anket sorularına verilen yanıtlar ile tespit edilmiştir. Çizelge 5 'te turizm ve rekreasyon potansiyeli bakımından değerlendirilen alanların yüzdelik dilimleri ve alan büyüklükleri gösterilmiştir.

Çizelge 5. Turizm ve rekreasyon potansiyeli uygunluğu değerleri

\begin{tabular}{|l|l|r|r|}
\cline { 2 - 4 } \multicolumn{1}{l|}{} & Turizm ve Rekreasyon Potansiyeli Uygunluğu & $\mathbf{\%}$ & HA \\
\hline $\mathbf{1}$ & Uygun değil & 31,98 & $\mathbf{2 2 . 9 4 5 , 4 5}$ \\
\hline $\mathbf{2}$ & Az uygun & 25,37 & $18.203,40$ \\
\hline $\mathbf{3}$ & Orta uygun & 22,94 & $16.459,22$ \\
\hline $\mathbf{4}$ & Uygun & 14,52 & $10.416,70$ \\
\hline $\mathbf{5}$ & Çok uygun & 5,21 & $3.735,23$ \\
\hline & TOPLAM & $\mathbf{1 0 0}$ & $\mathbf{7 1 . 7 6 0 , 0 0}$ \\
\cline { 2 - 4 } &
\end{tabular}

Buna göre Burdur İli'nde \% 31,98'lik oranla 22.945,45 hektarlık alanın uygun olmadığı sonucuna ulaşılmıştır. Çalışma alanının 3.735,23 hektarlık bölümü turizm ve rekreasyon faaliyetleri için çok uygun olarak ortaya çıkmıştır. Turizm potansiyeli uygunluğunun belirlenmesi için kullanılan soruların katsayı değerleri, alan kullanıılarının bir alandan daha etkin faydalanma ve tercih etme kriterlerini de ortaya koymaktadır. Bu kriterler doğrultusunda Burdur ili için "Turizm ve Rekreasyon Uygunluk Haritası" (Şekil 7) ortaya konulmuştur. 


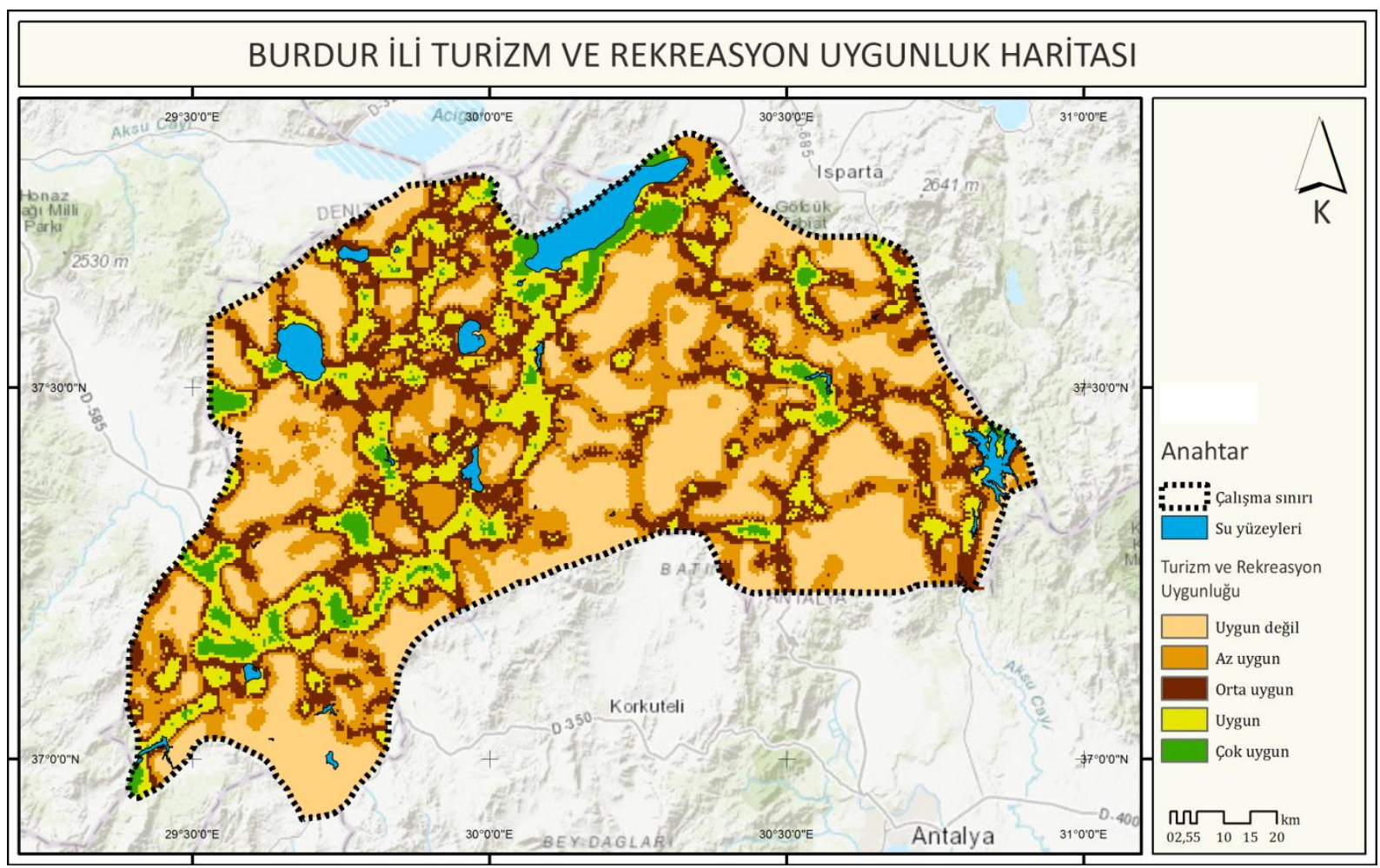

Şekil 7. Burdur ili turizm ve rekreasyon uygunluk haritası (Orijinal, 2019)

Turizm ve rekreasyonel uygunluk haritası, Burdur ili'ne ait turistik ve rekreasyonel değerlerin, ankette bulunan sorulara verilen ağırlıklı yanıtlar ve bu yanıtların frekans değerleri kullanılarak elde edildiği gibi, bu uygunluk aynı zamanda Burdur İli'ne özgü "Turizm ve Rekreasyon Potansiyeli" değerlerini de sunmaktadır. Bu değerlere ait yüzdelik dilimler ve alan büyüklükleri Çizelge $6^{\prime}$ da gösterilmiştir.

Çizelge 6. Turizm ve rekreasyon potansiyeli uygunluğu değerleri

\begin{tabular}{|r|l|r|r|}
\cline { 2 - 4 } \multicolumn{1}{l|}{} & Turizm ve Rekreasyon Potansiyeli Değeri & \% & HA \\
\hline $\mathbf{1}$ & $(-1,34)-(-1,00)$ & 16,87 & $12.102,79$ \\
\hline $\mathbf{2}$ & $(-1,00)-(0,00)$ & 32,07 & $23.013,22$ \\
\hline $\mathbf{3}$ & $(0,00)-(1,00)$ & 27,36 & $19.634,57$ \\
\hline $\mathbf{4}$ & $(1,00)-(2,00)$ & 16,03 & $11.500,96$ \\
\hline $\mathbf{5}$ & $(2,00)-(3,00)$ & 5,39 & $3.865,92$ \\
\hline $\mathbf{6}$ & $(3,00)-(4,00)$ & 1,98 & $1.418,26$ \\
\hline $\mathbf{7}$ & $(4,00)-(5,00)$ & 0,22 & 154,9 \\
\hline $\mathbf{8}$ & $(5,00)-(6,00)$ & 0,04 & 30,66 \\
\hline $\mathbf{9}$ & $(6,00)-(7,00)$ & 0,04 & 29,04 \\
\hline $\mathbf{1 0}$ & $(7,00)-(7,58)$ & 0,01 & 9,68 \\
\hline & TOPLAM & $\mathbf{1 0 0}$ & $\mathbf{7 1 . 7 6 0 , 0 0}$ \\
\cline { 2 - 4 } & & &
\end{tabular}

Turizm ve rekreasyon potansiyeli değerlendirmesinde de görüldüğü üzere elde edilen değerler anket sorularındaki çarpanları ile formüle edildiğinde, turizm uygunluk haritası ile paralel sonuçlar içermektedir. Burdur ili'nde rekreasyon açısından değerli özelliklere sahip ve çarpan değeri olarak en yüksek puan alan toplamı 968 hektardır. Ankete verilen tüm yanıtlar doğrultusunda, Burdur ili'ne ait turizm ve rekreasyon potansiyeli haritası oluşturulmuş ve Şekil 8' de gösterilmiştir. 


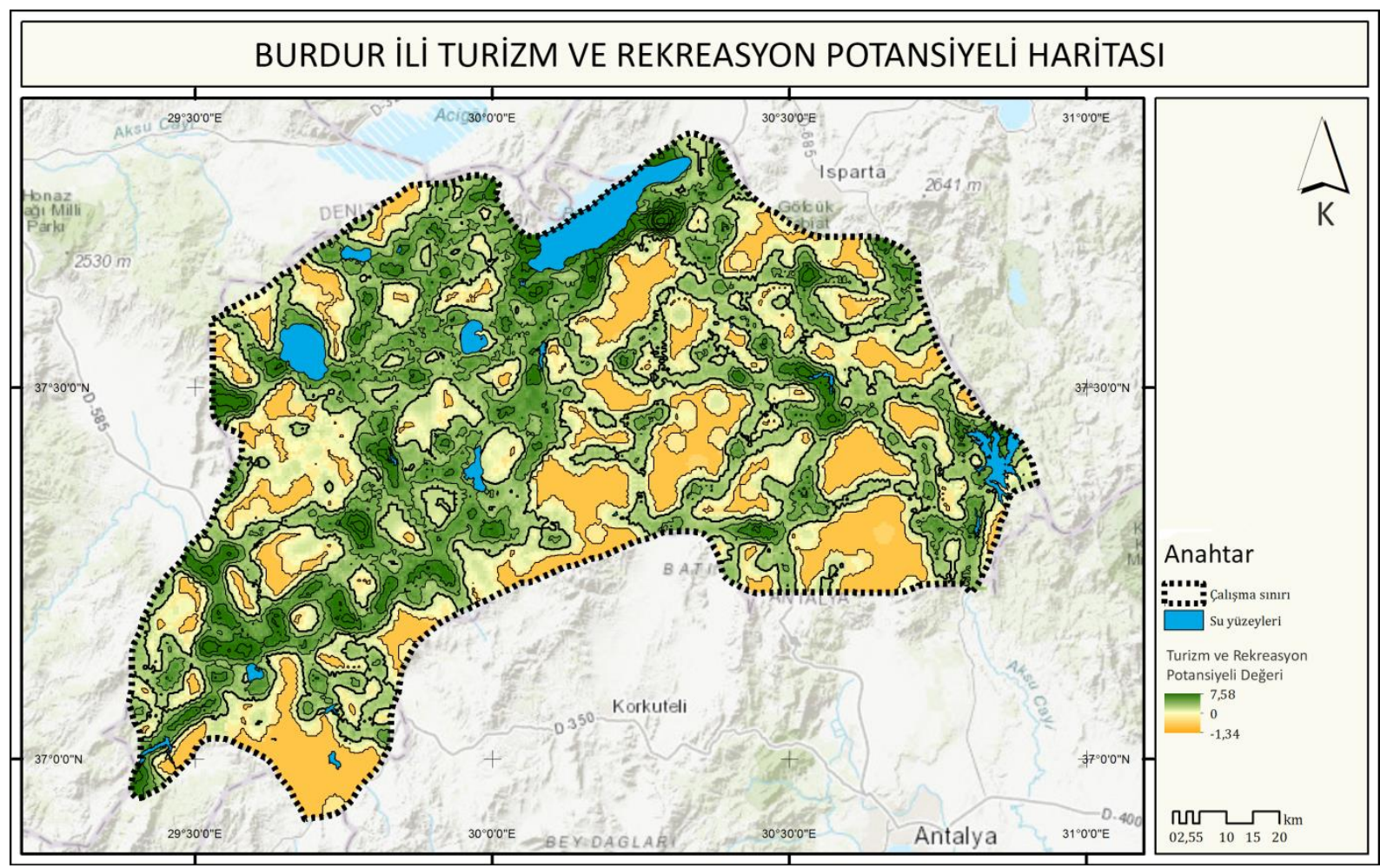

Şekil 8. Burdur ili turizm ve rekreasyon potansiyeli haritası (Orijinal, 2019)

\section{Sonuç ve Öneriler}

Yerel halkın ve günübirlik kullanıcıların rekreasyon eğilimlerinin anket ile test edildiği bu çalışmada ortaya çıkan sonuçlar ile davranış biçimleri paralellik gösterse de değişen bazı ihtiyaçların karşılanması için kullanıcıların alan tercihlerinin saptanması ve buna yönelik çalışmalar yapılması ile gerekmektedir.

Çalışma alanı olan Burdur ili'nde yerel halk ve günübirlik kullanıcılara yönelik yapılan 386 adet ankette katılımcıların demografik özellikleri değerlendirilmiştir. Kadın ve erkeklerin turizm ve rekreasyon faaliyetlerine birbirine yakın oranda (\% 45 kadın, \% 55 erkek) katılım sağladıkları görülmüştür. Bu nedenle Burdur îli genelinde turizm ve rekreasyonel potansiyeli belirlenmiş alanlar hakkında çalışma yaparken her iki cinsiyet grubuna yönelik ihtiyaçların karşılanmasını önemseyecek şekilde peyzaj planlamaları ve peyzaj tasarımları yapılmalıdır. Anket sonuçlarına göre evli ve ailesi ile aktivitelere katılan bireylerin sayısı oldukça fazladır. Bu nedenle bölgede bir ailedeki kadın, erkek ve çeşitli yaşlardaki çocukların yeme, içme, eğlenme ve dinleme ihtiyaçlarını giderebilecek türden kullanımlar hizmete sunulmalıdır. Bu hizmetler, aile içindeki her bireye kullanım konforu sağlamalı ve her birey için özenle dikkate alınmalıdır.

Talay vd. (2010)'nin de vurguladığı üzere; turizm ve rekreasyonda sürdürülebilirliğin gerçekleşmesi için akılcı planlama ve doğru yönetim için çeşitli alternatifler geliştirilmesi gerekmektedir. Tüm bu alternatif yaklaşımlar ve yönetim planları geliştirme faaliyetleri çalışılan alanın niteliklerine, ekonomik değerine ve alan kullanııısının tercihleri üzerine belirlenmektedir.

Anket katılımcılarının alan kullanım tercihleri belirlendiğinde; Burdur ili'ndeki rekreasyonel kullanımların en başında gelen göl ve göl manzarası olan alanlardır. Katılımcıların \% 31,36'sı, göl ve göl manzarası olan alanları rekreasyonel aktiviteler için tercih etmektedirler. Bu da suyun; dış mekân rekreasyonu için oldukça önemli bir bileşen olarak öne çıktığı (Driver ve Tocher, 1970) görüşünü destekler.

Elde edilen sonuçların su ögesi ile ilgili olan bölümünün verilen yanıtlara göre toplam oranı \% 39,22 olması Göller Yöresi'nde bulunan ve su ile doğrudan ilişki içinde olan Burdur illi için, tüm dış mekân rekreasyonunun dörtte biri suyla ilişkilidir (Pitt, 1989), görüşünü ortaya koyan görüşü destekler niteliktedir. Su, peyzajda ne tür bir formda olursa olsun daima cezbedici nitelikte bir özelliktir. Ayrıca 
estetik yönden katkıları ve kıymeti olduğu kadar yüzme, balıkçılık, ve kayıkla gezinti için de değerli önemli bir rekreasyon kaynağıdır (Bell, 1997).

Göl ve göl manzarası olan alanlardan sonra en çok tercih edilen alanlar; \% 16,71 ile akarsu ve dere kıyılarıdır. Çalışma alanında bulunan akarsu ve dereler, bir koridor boyunca insanları etrafına çekmektedir. Bu sonuç; geçmişten günümüze su kenarlarının ulaşım, yerleşim, turizm ve rekreasyon gibi kullanımlara hizmet etmiş, bu amaçlara göre planlanarak tasarlanmış (Arslan Muhacir ve Özalp, 2018) olması görüşü ile paralellik göstermektedir. Ayrıca farklı büyüklüklerde bulunan akarsular; peyzaj içinde rekreasyonel olduğu kadar fonksiyonel açıdan da önemli bir kaynak olma özelliğindedir. Bir akarsuyun doğal drenaj hattı olmasının yanı sıra, bulunduğu bölge içinde koridor niteliğinde bir alan kaplamakta ve bölgeler arası iletişimi de sağlama görevindedir (Yıldırım vd., 2013).

Rekreasyonel aktivitelere katılım sıklığına bakıldı̆ı̆nda; en yüksek yüzdelik oran \% 36,5 ile 15 günde bir katılım yapılması yönündedir. Yılda bir katılımı tercih eden grup ise en az kişi sayısını $(\% 1,8)$ oluşturmaktadır. Rekreasyonel faaliyetlerde gündelik hayata ait stresten uzaklaşmanın esas olduğunu düşündüğümüzde en az katılımın yılda bir gerçekleşiyor olması oldukça beklenen bir durumdur. Turizm ve rekreasyon potansiyeli, alana aktif kullanılabilir bir nitelik kazandırıması noktasında katıım sıklığı ile belirlenen potansiyel değeri bir arada düşünülmelidir.

Çalışma alanı içindeki en yüksek turizm ve rekreasyon potansiyeli değeri; Burdur merkez ilçesinin de içinde bulunduğu bölgede görülmektedir. Anket katılımcıları tarafından belirlenen ve alan değerinin yüksek ortaya çıkmasına neden olacak güvenlik, konaklama olanakları, ulaşılabilirlik, göl manzarasına sahip olma ve çevre düzenlemesi açısından bu alan öne çıkmaktadır. Merkezi bir konumda bulunan Burdur Gölü, sahip olduğu ekolojik ve turistik değerler bakımından da alana değer katmaktadır. Sosyo-kültürel ve altyapı olanakları gibi kültürel faktörlerin yanı sıra bölgenin eğim ve güneşlenme durumu, su yüzeyine sahip olması ve bölgenin geniş bir bölümünden de bu su yüzeyinin görülebilmesi gibi coğrafik faktörler nedeniyle de turizm ve rekreasyonel değer açısından avantajlı konumdadır.

Burdur Gölü Güneydoğusundaki alana bakıldığında, bu alanın en çok jeomorfolojik yapısı nedeniyle geri planda kaldığı ve bu nedenle de alan değerini yükseltecek diğer faktörlerin de buna bağlı olarak gelişemediğini söylenebilir.

Salda Gölü ile Yarışlı Gölü’nün de içinde bulunduğu Burdur ili'nin Yeşilova İlçesi'ni içine alan batı kesimine bakıldığında genelde orta derecede bir turizm ve rekreasyon potansiyeline sahip olduğu görülmektedir. Salda Gölü ve çevresindeki uygun jeomorfolojik yapı ve son yıllarda daha popüler olması ve buna bağlı olarak bölgede gelişen günübirlik kullanım olanakları, yeme içme imkanlarına sahip olması ve çevre düzeni yönünden de dikkate alındığında bu alanının turizm ve rekreasyon potansiyelinin yüksek çıkması beklenen bir sonuçtur. Ulaşılabilirliği ve çevre göllere göre farklı imkânlar sunması nedeniyle Salda Gölü önümüzdeki yıllarda da turizmdeki yerini giderek artıracaktır.

En derin noktası 2 metre olan ve özellikle kuş gözlemciliği yönünden oldukça büyük bir öneme sahip olan Yarışlı Gölü ve çevresi güvenilir bir noktada olması, ulaşılabilir olması, yayla ve mesire alanlarına yakın olması ve jeormorfolojik yapısının uygunluğu nedeniyle turizm ve rekreasyon potansiyeli yüksek bir profil çizmektedir.

Burdur ili'nde gölleri besleyen yer altı ve yer üstü suların varlığı, bölgeye olumlu yönde bir değer katmaktadır. Altınyayla, Gölhisar ve Çavdır İlçeleri'nin içinde bulunduğu bu kesimde özellikle akarsuların bulunması ve alanlara ulaşılabilirliğin olması nedeniyle turizm ve rekreasyon potansiyeli yüksek değerde çıkmıştır. Diğer tüm olumlu faktörlerden daha çok ön plana çıkan akarsu ve derelerin varlığı bu bölgede değerlendirilmesi gereken doğal bir peyzaj unsurudur.

\subsection{Burdur ili için öneriler}

Burdur ïline dair öne çıkarılması gereken temel peyzaj değerlerin tespiti oldukça önemlidir. Bu tespit, tarihi eserleri, kültürel ve doğal güzellikleri, kırsal turizme elverişli alanların tespiti ile mümkün olacaktır. İlin özellikle göl turizmi açısından değerlendirilmesi gerekmektedir. Burdur Gölü, Salda Gölü ve Yarışlı Gölü sahip olduğu doğal değerlerin kolayca ön plana çıkarılabileceği çekim noktalarıdır. 
Bölgenin yüksek turizm ve rekreasyon değerine sahip olmasında önem derecesi ve katkısının büyük olduğundan bu göllerin ekolojik yönden varlığının devamlılığına hassasiyet gösterilmelidir.

Burdur Ili'nde bulunan göller, yılın her mevsimi olmak üzere özellikle kuşların göç zamanı ortaya çıkan manzaraları fotoğraflamak için çeşitli bölgelerden turist çektiği kadar yerli halkın da ilgisini çekmektedir. Anket sonuçlarında ortaya çıkan doğa yürüyüşü ve fotoğraf çekme etkinliklerinin toplam içinde \% 29,54'lük bir değere sahip olması, yerel halkın Burdur doğasına ne denli ilgili olduklarını ortaya koyar. Bu aktivitenin geniş kitlelere yayılabilmesi için fotoğraf ve gezi kulüpleri işbirliğinde turlar düzenlemelidir.

Salda Gölü’nden sonra en yoğun kullanım, Burdur il sınırı içinde bulunan ve gün geçtikçe çekilen Burdur Gölü ve çevresi olmuştur. "Göl Yoksa Burdur da Yok!" sloganı ile yerel ve ulusal ölçekte göle dikkat çekmeyi hedeflemiş türde kampanyaların sayısı ve etkinliği artırılmalıdır.

İldeki mermer ocağı faaliyetleri kontrol altında alınmalı ve denetimlerinin takibi yapılmalıdır. Mermer ocaklarının doğal ve görsel tahribatının önüne geçilmesi için ilgili kurum ve kuruluşlarca yasal düzenlemeler yapılmalıdır.

\subsection{Turizm ve rekreasyon faaliyetleri üzerine öneriler}

Doğal yapısından kaynaklı kırsal turizme elverişli bir bölge olan Burdur'da; çiftlik turizmi, göl turizmi, kuş gözlemciliği ve yayla turizmi faaliyetlerine yoğunlaşılmalıdır. Alternatif turizm faaliyetlerinin gelişimi sağlanarak bölgede oluşacak istihdam ile genç nüfusun göçü engellenmelidir.

Günübirlik kullanım ve kamp yapmak üzere belirlenmiş anların temiz kalması ve doğal güzelliğin tahrip edilmemesi için bölge titizlikle takip edilmelidir. Bölgenin ziyaretçi sayısının, yoğun kullanım dönemlerinin, kullanıcı profilinin ve eksikliklerin belirlendiği çalışmalar ile alana yönelik tehditler yılın her döneminde denetlenmelidir.

\subsection{Peyzaj mimarlığı meslek disiplini için öneriler}

Kentsel alanlardaki turizm ve rekreasyon alanları kısıtlı vakitlerin değerlendirileceği ve insanları kent yaşamı kargaşasından uzaklaştıracak kullanım alanları ile zenginleştirilmelidir. Aynı zamanda bölgeye dair alt ve üstyapı olanaklarının gelişimi sağlanmalıdır. Toplum içinde vatandaşların fiziksel ve zihinsel gelişimine katkı sunacak dinlenme ve yaşam alanları, sosyalleşme ve yaratıcılığın gelişmesi için gereken niteliklerde düzenlenmiş projeler, planlama aşamasından itibaren dikkate alınarak hazırlanmalıdır.

Burdur Valiliği ile İl Kültür ve Turizm Müdürlüğü tarafından hazırlanmış olan doğa yürüyüşü ve bisiklet parkurlarının dışında bu faaliyetlerin yapılması önlenmelidir.

Doğanın ve peyzajın rekreasyonel amaçlı kullanımı için önemli bir ön şart ulaşılabilirliktir. Ancak yalnızca bu amaç için rekreasyonel altyapının uygunsuz şekilde genişletilmesinden ve alan tahribatından özellikle de habitat bölünmelerine yol açabilecek tahribatlardan kaçınılmalıdır. Mevcut peyzaj değerleri ve ekolojik bağlantılar, ulaşım ağlarının yapılaşması nedeniyle zarar görmemelidir. Ulaşım eksikliği nedeniyle azalan turizm ve rekreasyon alanlarının değeri, ulaşım ağlarının ekolojik planlama ilkeleri doğrultusunda hazırlanması ile yükseltilebilir.

Orman vejetasyonu yönü ile de zenginliğe sahip olan Burdur ili'nde orman alanları içinde rekreasyon alanlarının kullanılabilirliği üzerine çalışmalar yapılmalıdır. Göller çevresindeki kullanımdan kaynaklı baskının azaltılmasına yönelik çalışmalar yapılmalı, yerel halkın bilinçlendirilmesine yönelik eğitim programları düzenlenmelidir.

\subsection{Koruma kullanma dengesi ve sürdürülebilirlik için öneriler}

Burdur Il'inde doğa tabanlı projeler ile turizmin gelişmesine katkı sunulmalıdır. Gönüllü faaliyet gösteren Lisinia Doğa Projesi örnekleri çoğaltılmalıdır. Ekoturizm faaliyetlerinin yapılabileceği alanlar belirlenerek, ekoturizm temelli bir çalışma için hazırlanmış haritalarda doğru yer seçimleri yapılmalıdır. 
Göllerin yakınında oluşabilecek su kirliliğine dikkat çekmek ve suların geri çekilmesi hakkında yerel halkın bilinç düzeyinin artırılması yönünde halk eğitim programları düzenlenmelidir. Taban suyu sondajı konusunda yasal düzenlemeler getirilerek bu faaliyetin su seviyesi üzerindeki olumsuz etkileri azaltılmalıdır.

Zaman içerisinde değişebilecek hedef kitlenin takibi yapılmalıdır. Değişmekte olan beklentiler, sosyoekonomik koşullar, yeni yaklaşımlar ile paralellik göstermelidir. Tüm yerel yöneticiler bu ihtiyaç ve değişimleri dikkate almalıdırlar.

\subsection{Engelli, yaşlı ve kısıtlı kullanıcılar için öneriler}

Mevcut ulaşım ağlarının doğala yakın olması kadar engelli bireylerin de kullanımını kısıtlamayacak nitelikte ve uygun mühendislikte olması gerekmektedir. Planlanan ve uygulanan projelerin tamamındaki çözümler, engelli bireylerin kullanımına imkân verecek şekilde yapılmalıdır.

Katılımcıların \% 34,7'si 36-45 yaş grubuna ait bireyler tarafından oluşmaktadır. Bu yaş aralığının intiyaçları diğer meslek disiplinleri ile değerlendirilip ziyaretlerinin devamlılığını sağlanmalıdır. En az katılım 66 yaş ve üzeri bireyler tarafından gerçekleştirilmektedir. Bu nedenle turizm ve rekreasyon faaliyetlerinde katıımın yaşı bireylerin katılımını destekleyecek içeriğe sahip etkinliklerin sayısı artırımalıdır.

Sonuç olarak; geliştirilen tüm öneriler ve peyzaj tasarımları şu özelliklere sahip olmalıdır:

- Her birey tarafından eşit kullanılabilir olmalı,

- Bireylerin tercihlerine ve yetilerine göre düşünülmeli,

- Basit ve anlaşılabilir olmalı,

- Alanlara doğru ve en kısa yönlendirmeler yapılmalı,

- Kolay erişilebilir olmalı,

- Güvenliği sağlanmalı,

- En az efor harcanarak alanlar kullanılabilmeli ve alan kullanımından en yüksek verim elde edilmelidir.

Burdur ili'ne ait turizm ve rekreasyon potansiyelinin belirlendiği çalışmanın sonuçları, bölgeye özgü bir kullanım tipinin geliştirilmesi gerekliliğini ortaya koymaktadır. Bölge turizm ve rekreasyon bakımından değerlendirilmesi gerektiği kadar, koruma-kullanma dengesinin de sağlanması gereken hassas alanlara sahiptir. Sürdürülebilir turizm faaliyetleri, dengede bir ekoloji kaygısı ve doğaya saygı ilkeleri birlikte uygulanmalıdır.

Burdur ili için ortaya konan bu veriler ve öneriler; peyzaj mimarı, mimar, şehir plancıları, sosyolog, biyolog ve doğa bilimlerinin alt dallarında konusunda uzmanlaşmış meslek insanlarının ortak çalışması sonunda geliştirilerek nitelikleri artırılabilir. Çalışma; tüm bu meslek grupları ile yürütülen ortak çalışmalar ile sürdürülebilir kalkınma sağlama yönünden değerlendirilmelidir. Bu anlamda çalışma, farklı bakış açılarında projeler geliştirebilmek için bir altık görevi üstlenmektedir. Adımlar doğru ve etkin atıldığında hem yerel halk, hem bölge halkı hem de uzun vadede ülke ekolojisi ve ekonomisi adına katkılar sunulmuş olacaktır.

\section{Teşekkür ve Bilgilendirme}

Çalışmada Burdur Gölü ve çevresine ait alanların turizm ve rekreasyon potansiyeli, mevcut peyzaj değerleri incelenerek ortaya konmuştur. Bölge turizmine Burdur illi sınırlarında katkı sunmayı amaçlayan bu makale; Süleyman Demirel Üniversitesi, Fen Bilimleri Enstitüsü, Peyzaj Mimarlığı Ana Bilim Dalı'nda yüksek lisans tezi olarak ele alınan; "Peyzaj Değerleri Açısından Turizm Ve Rekreasyon Potansiyelinin Belirlenmesi: Burdur Örneği" isimli çalışmadan üretilmiştir.

\section{Kaynaklar}

Ala, Z. (2001). Burdur Yerleşim Alanı ve Çevresinin Hidrojeoloji İncelemesi. Süleyman Demirel Üniversitesi, Fen Bilimleri Enstitüsü, Yüksek Lisans Tezi, 79s, Isparta. 
Arslan Muhacir, E. S., Özalp, A. (2018). Kıyı Alanlarının Rekreasyonel Amaçlı Alternatif Kullanımının Artvin Örneğinde İrdelenmesi. Bartın Orman Fakültesi Dergisi, 20(1), 43-52.

Bell, S. (1997). Design for Outdoor Recreation, 240s, Spon Press, London.

Can, E. (2015). Boş Zaman, Rekreasyon ve Etkinlik Turizmi ilişkisi. İstanbul Sosyal Bilimler Dergisi, 10, 1-17.

Driver, B.L., Tocher, S.R. (1970). Elements of outdoor recreation planning Tocher. Toward a Behavioral Interpretation of Recreational Engagements. 9-31.

Evliyaoğlu, S. (1994). Türkiye Turizm Coğrafyası ve Türkiye Coğrafyası'nın Ana Hatları. Gazi Üniversitesi Yayınları, 206s, Ankara.

Gıran Taşcıoğlu, G. (2016). Sürdürülebilir Turizm İçin Stratejilerin Geliştirilmesi: Kuzey Antalya Kültür Ve Turizm Koruma Ve Gelişim Bölgesi Örneği. Ankara Üniversitesi, Fen Bilimleri Enstitüsü, Doktora tezi, 413 s, Ankara.

Günal, N. (2013). Türkiye'de İklimin Doğal Bitki Örtüsü Üzerindeki Etkileri. Çevrimiçi Tematik Türkoloji Dergisi, 1, $1-22$.

Kubat, A., Ayaşlıgil, T. (2002). Doğa Bilimlerinde Ki-Kare Bağımsızılıık Testi ve Tek Yönlü Varyans Analizi Testi Uygulamasında SPSS Programı Kullanımı. İstanbul Üniversitesi Orman Fakültesi Dergisi, 52(1), 155-167.

Mehrhoff, W.A. (1991). The new frontier: A case study of cultural tourism. Canadian Review of American Studies, 22(2), 251-262.

Örücü, Ö.K. (2002). Eğirdir Yöresindeki Mevcut Peyzaj Değerlerinin Turizm Açısından İrdelenmesi. Süleyman Demirel Üniversitesi, Fen Bilimleri Enstitüsü, Yüksek Lisans Tezi, 136s, Isparta.

Özbay, Ö. (2008). Çapraz Tablo Analizi Nasıl Yapılır? Pratik Bir Açıklama. Hacettepe Üniversitesi Türkiyat Araştırmaları Dergisi. 9, 460-47

Öztaş, K., Karabulut, T. (2007). Turistik Destinasyon Oluşturma Potansiyeli Açısından Göller Yöresinin Önemi. Selçuk Üniversitesi Karaman İ. İ. B. F. Dergisi, 12, 128-137.

Pitt, D.G. (1989). The Attractiveness and Use of Aquatic Environments as Outdoor Recreation Places In Public Places and Spaces. 217-54.

Richards, G. (1996). The Scope and Significance of Cultural Tourism, in Cultural Tourism in Europe, 19-45.

Talay, İ., Akpınar, N., Belkayalı, N. (2010). Doğal Kaynakların Rekreasyonel ve Turizm Amaçlı Kullanımının Ekonomik Değerinin Tespiti: Göreme Tarihi Milli Parkı Örneği. Coğrafi Bilimler Dergisi, 8(2), 137-146.

Yazıcıoğlu, Y., Erdoğan, S. (2004). SPSS Uygulamalı Bilimsel Araştırma Yöntemleri, Detay Yayıncılık, 323s, Ankara.

Yıldırım, E., Yılmaz, T., Benliay, A. (2013). Peyzaj Planlamada Akarsu Ekolojisinin Önemi, Türk Bilimsel Derlemeler Dergisi 6 (1), 51-54.

Zeğerek, P. (2016). Yeşil Alanların Kent Turizmine Katkısının Antalya Örneğinde İncelenmesi. Akdeniz Üniversitesi Fen Bilimleri Enstitüsü, Yüksek Lisans Tezi, 116s, Antalya.

URL-1. http://www.burdur.gov.tr/cografi-yapi, Erişim Tarihi: 26.02.2019

URL-2.http://www.cygm.gov.tr/cygm/anasayfa/sutoprakyonetimi/havzakoruma.aspx?sflang=tr, Erişim Tarihi: 01.03.2019.

URL-3. http://bolge6.ormansu.gov.tr/6bolge/Files/duyurular/burdur_ili_doga_turizmi_master_plani.pdf, Erişim Tarihi: 24.02.2019.

URL-4. http://www.burdur.gov.tr/cografi-yapi, Erişim Tarihi: 26.02.2019.

URL-5. http://www.burdur.gov.tr/goller, Erişim Tarihi: 26.02.2019.

URL-6. http://tuik.gov.tr/UstMenu.do?metod=temelist, Erişim Tarihi: 30.01.2018. 